\title{
NUOLATINĖS PRIVALOMOSIOS PRADINĖS KARO TARNYBOS KARIŲ TARNYBOS MOTYVACIJA: SUBJEKTYVUS DALYVIŲ VERTINIMAS
}

\author{
Gerda Baltutytè \\ Klaipédos universitetas
}

\begin{abstract}
Anotacija
Straipsnyje analizuojama Lietuvos kariuomenès karių tarnybos motyvacija, remiantis jų nuomonėmis. Formuluojama karių tarnybos motyvacijos teorinė prieiga, akcentuojama vertybių reikšmé motyvacijos procese, išskiriami lūkesčiai, remiantis V. H. Vroom'o lūkesčių teorija, kurie lemia nuolatinę privalomają tarnybą atliekančių karių tarnybos motyvaciją. Remiantis atlikto tyrimo analize teigiama, kad esama karių tarnybos motyvacijos sistema patys kariai patenkinti tik iš dalies. Be to, tyrimo rezultatai leidžia patvirtinti suformuluotą hipotezę ir teigti, kad savanoriškai bei privaloma tvarka atliekančių nuolatinę privalomają pradinę karo tarnybą (toliau - NPPKT) karių tarnybos motyvacija skiriasi, nes jų karo tarnybą lemiantys lūkesčiai nèra tapatūs.

PAGRINDINIAI ŽODŽIAI: nuolatinè privalomoji pradinè karo tarnyba, kariai, tarnybos motyvacija.
\end{abstract}

\begin{abstract}
The article analyzes the motivation for military service of the soldiers the Lithuanian Armed Forces based on their opinion. It presents the theoretical approach to motivation for military service, emphasizes the significance of values in the process of motivation, identifies the expectations, based on V. H. Vroom's expectancy theory, which determine the motivation of soldiers under continuous mandatory service. According to the analysis of the completed research, it is stated that the soldiers are only partly satisfied with the current motivation system. In addition, the results of the research confirm the hypothesis that the motivation for military service differs between volunteer soldiers and conscript soldiers.
\end{abstract}

KEY WORDS: continuous mandatory initial military service, soldiers, motivation for military service.

DOI: http://dx.doi.org/10.15181/tbb.v82i1.1959

\section{Ivadas}

Svarbiausių pasaulio ịvykių grandinėje karas ir kariuomenė vaidina išskirtini vaidmenį. „Gynybą nuo išorinių (pirmiausia karinių) grèsmių užtikrina valstybė, o valstybès - pagrindiniai tarptautinių santykių objektai, tarptautiniams santykiams esant anarchinès būklès, nuolat siekia didinti galią, kad užsitikrintų saugumą“" (Jokubauskas, 2014, p. 13). Valstybès turi gebèti aktualizuoti ir formuoti individualius bei kolektyvinius kompleksinius saugumą užtikrinančius veiksmus. 
Kariuomenę sudaro kariai, o karys yra lankstus išteklius, kuris, atsižvelgiant i kuriamą aplinką, gali veikti blogiau arba geriau, taigi aktuali tampa motyvacija, šiuo klausimu diskutuoja ne tik mokslininkai, bet ir visuomenè. Motyvacija yra svarbus procesas, keičiantis organizacinès sistemos elgseną. Be to, motyvacija yra subjektyvus apsisprendimas ir požiūrio dalykas (neatmetant prielaidos, kad subjektyviai pozicijai turi įtakos tam tikri veiksniai). Todèl tarnybos motyvavimas yra vienas reikšmingiausių praktinių pokyčių vykdymo determinantų, tobulinant Krašto apsaugos sistemą. Kaip teige Krašto apsaugos ministerijos (toliau - KAM) gynybos planavimo departamento vedejja K. Šapkinaitė, karių motyvacijos klausimas yra aktualesnis nei ginklų ar ịrangos klausimas (remiantis: Jonušas, 2018). Krašto apsaugos ministras R. Karoblis pabrèžè, kad kario motyvacija kariuomenèje yra visa ko pagrindas (remiantis: Jakilaitis, 2017).

Pasikeitus geopolitinei situacijai, 2015 m. sugrąžinta šauktinių tarnyba, kuri 2008 m. buvo panaikinta. Per ši laikotarpi, kol nebuvo privalomosios pradinès karo tarnybos, Lietuvoje egzistuojančios karinès tarnybos formos (Krašto apsaugos savanorių pajėgos, baziniai kariniai mokymai, profesine karo tarnyba, jaunųjų vadų kursai) tuo metu rèmèsi savanoriškumo principu (Vileikienè ir kt., 2015). Tačiau, remiantis KAM duomenimis, nuo 2015 m. vèl turime ne tik karius savanorius, bet ir karius prievolininkus, nes nuolatinès privalomosios pradinès karo tarnybos karių tarnyba grindžiama ne tik savanoriškumo principu, bet ir prievarta (už šaukimo atlikti privalomają pradinę karo tarnybą vengimą įstatymų numatytos bausmès). Pripažịstant karių tarnybos motyvacijos svarbą, formuojasi poreikis ieškoti teorinio ir empirinio patvirtinimo, kuris, kaip atspirties taškas, leistų ịvertinti karių tarnybos motyvaciją.

Kalbant apie karių tarnybos motyvaciją, verta išskirti C. Moskos’o (1977) karinę sociologiją. Jis analizavo kariuomenès instituto kaitą, ją susiedamas su karių motyvacijos svarba. Vèliau prie jo darbų tobulinimo prisidejo F. Battistelli (1997), Y. Levy (2007) ir kt. Lietuvos kariuomenès karių tarnybos motyvacijos tema atliktų tyrimų nėra gausu dèl griežtos vyriausybinių institucijų kontrolès. Paminètina Generolo Jono Žemaičio Lietuvos karo akademijos Karo mokslų instituto Strateginių tyrimų centro parengta mokslo studija „Motyvacija tarnauti Lietuvos kariuomenèje“ (2015). Vienas naujausių tyrimų - A. Pocienès (2018) straipsnis „Lietuvos jaunuolių pritraukimo ị nuolatinę privalomąą pradinę karo tarnybą galimybės“. Kol kas mokslinès medžiagos apie realią Lietuvos kariuomenès karių tarnybos motyvaciją trūksta ${ }^{1}$.

Tiriamosios problemos esmę sudaro faktas, kad Krašto apsaugos sistemoje neimanoma ịvykdyti efektyviai užsibrèžtų tikslų be kario pastangų ir indèlio. Šiuo

Pažymėtina, kad Lietuvos kariuomenès karių ir karininkų motyvacijos tyrimai atliekami ir magistrų baigiamujų darbų lygmeniu (Razma, 2014; Vasiljevas, 2015; Baltutytè, 2019). 
atveju išryškejja karių tarnybos motyvacijos svarba. Valdžios institucijų funkcija ne tik taikyti sankcijas, bet ir skatinti karius ịsitraukti ị bendrą veiklą. Norint juos ịtraukti, būtina išsiaiškinti lūkesčius, kodèl jie apsisprendžia dalyvauti arba tarnyboje lieka pasyvūs. Mokslinė ir praktinė problema formuluotina klausimu, kas lemia nuolatinę privalomają tarnybą atliekančių karių tarnybos motyvaciją ir kaip jie vertina dabartinę Lietuvos kariuomenès motyvavimo sistemą?

Tyrimo tikslas: išanalizuoti nuolatinės privalomosios pradinès karo tarnybos (NPPKT) karių tarnybos motyvaciją, atskirai tiriant karius, kurie ją atlieka privaloma tvarka, ir tuos, kurie savanoriškai pasirinko atlikti NPPKT.

Remdamiesi tiek teorinemis prielaidomis, tiek empiriniais tyrimais keliame hipotezę, kad savanoriškai ir privaloma tvarka atliekančių NPPKT karių tarnybos motyvacija turi skirtis, nes jų karo tarnybą lemiantys lūkesčiai nèra tapatūs. Karo tarnybos motyvacijai esminès įtakos turi savanoriškumo principu grindžiamas atejjimas ị karinę tarnybą.

Atliekant tyrimą taikyti mokslinès literatūros, dokumentų analizès, duomenų kaupimo anketinès apklausos būdu metodai.

\section{Karių tarnybos motyvacija}

Didejjanti kario motyvacijos svarba skatina išsamiau nagrinèti šią temą. Nuo seniausių laikų armijų vadai susidurdavo su kareivių ir naujokų motyvacijos problemomis (Statkus, 2003). Dažniausia motyvacija siejama su lotynų kalbos žodžiu motivere, kuris reiškia judèjimą, veiksmą, veiklos priežastį, elgseną. R. Semler'is (2003), F. Malik'as (2005) teigia, kad motyvacija yra jèga, kuri išjudina ir nukreipia žmogų pasirinkti tam tikrą veiklą ir pastangų intensyvumą (remiantis: Marcinkevičiūtè, 2010, p. 40). Panašiai motyvaciją apibrèžia ir D. Lipinskienè (2012): tai jèga, kuri suteikia individui energijos ir nurodo jo elgsenos kryptị bei yra siekio ir nusiteikimo veikti toliau, susidūrus su kliūtimis, pagrindas. Taigi motyvacija grindžiama nuostata, kad ji ịkvepia ir skatina žmogų eiti ị priekị, siekiant užsibrèžtų tikslų.

Remiantis Generolo Jono Žemaičio Lietuvos karo akademijos Karo mokslų instituto Strateginių tyrimų centro parengta mokslo studija „Motyvacija tarnauti Lietuvos kariuomeneje“, siekiant suprasti ir paaiškinti karių motyvaciją, analizuojama A. H. Maslow'o teorija, akcentuojant individų poreikių hierarchiją. Vis dèlto straipsnio autore pažymi, kad karinę tarnybą atliekantys asmenys turi ne tik poreikių, bet ir tam tikrų lūkesčių, kurie tarnybos metu gali tapti motyvacijos ịrankiu. Kaip nurodo J. L. Perry (1996), kiekvienas ị instituciją ateina su savo „lūkesčių krepšeliu“, o vadovybei svarbu nustatyti jo turinị. Nepateisinti lūkesčiai gali trukdyti sèkmingai ir motyvuotai tarnybai. Analizuojant karių tarnybos mo- 
tyvaciją, remiamasi žinomiausia proceso motyvacijos - V. H. Vroom’o lūkesčių teorija, kurioje pabrèžiama, kad elgesị lemia sąmoningas pasirinkimas, įvertinus alternatyvas, kurių tikslas - kiek įmanoma padidinti malonumą ir sumažinti skausmą. V. H. Vroom'o teigimu, žmogaus veikla grindžiama individualiais veiksniais, tokiais kaip asmenybè, igūdžiai, žinios, pastangos, gebėjimai. Būtina atsižvelgti i tai, kad pastangos ir veiklos rezultatai yra susiję su asmens motyvacija, todèl mokslininkas išskyrė kintamuosiuos veiksnius (lūkesčiai, instrumentalumas, valentingumas), kaip motyvacijos pagrindą. Kadangi žmogaus elgesys turi įtakos institucijos veiklai, lūkesčių teorijos autorius pastebėjo: jei darbdavys mano, kad suteikè viską, ko reikia siekiant motyvuoti, ir tai veikia daugelị žmonių, vis dèlto tai nereiškia, jog veiks kiekvieną toje organizacijoje dirbantiji. Be to, žmogus dar turi tikèti, kad pasirinkta elgsena iš tiesų galès patenkinti jo lūkesčius (Sakalas, 2000). E. Stumbraitè-Vilkišienè (2013), remdamasi V. H. Vroom'o teorija, teigia, kad piliečiai, prieš pradèdami dalyvauti, pirmiausia svarsto, ko jie tikisi ir ko reikia, kad pasiektų trokštamus dalykus, ar jie turi tam gebejjimų, ar jiems tai aktualu? Kartu įvertina, ką duos jų pastangos. Kita vertus, piliečiai turi įvertinti dalyvavimo tikslą, problemą. Ši teorinè prieiga yra tinkama interpretuojant ir ieškant atsakymo, ar karių lūkesčiai atliekant karinę tarnybą pasiteisino? Būtina pažymèti, kad Lietuvoje jaunus žmones stengiamasi motyvuoti ateiti tarnauti: „NPPKT yra puikus būdas atlikti pareigą Tèvynei, neprilygstamas nuotykis ir geras finansinis postūmis gyvenimo pradžiai. Savo noru tarnybą atliekantis karys gali pasirinkti ir tarnybos vietą: veiksmo kupiną pėstininko kelią, griausmingą ir paraku dvelkiantị artileristo darbą, technikos žinias lavinanti ryšininko darbą bei kitas, ne mažiau

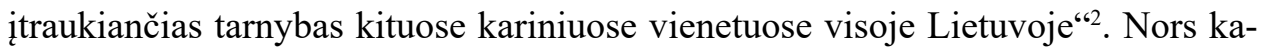
riams siūlomos realios galimybès, kurios gali juos sudominti, straipsnio autorè mano, kad atsakymo ị klausimą, kodèl jie tai privalo daryti, turi nuolat ieškoti ne tik ateinantys tarnauti, bet ir jau tarnaujantys kariai bei valdžios institucijos, siekiančios igyvendinti savo strategiją.

J. Griffith'as (2008) tyrinejjo jaunimo ir aktyvių karių motyvaciją tarnauti kariuomenejje, jis savo darbuose rèmèsi dviem motyvacijos tipais: instituciniu (patriotizmas, siekis save išbandyti, noras būti naudingam valstybei ir visuomenei) ir pragmatiniu (kariuomenè, kaip darbdavys, kuris teikia viliojančius pasiūlymus). Šiuo požiūriu asmenys tarnauja kariuomenèje dèl materialių ar nematerialių motyvų. P. Bury (2017) ir kitų autorių teigimu, kariai, turintys pragmatinių motyvų, paprastai mažiau patenkinti tarnybos sąlygomis. Dažnai teigiama, kad kariams motyvuoti trūksta lěšų, tačiau galima prielaida, kad tiesiog nežinoma, kaip be papildomų lěšų skatinti ir išlaikyti karių tarnybos motyvaciją. T. D. Woodruff'as (2017) pastebi, kad savanoriški įsitraukimo tikslai - tiek vidiniai, tiek išoriniai -

$2 \quad$ Prieiga internete: www.karys.lt 
gali puikiai karius motyvuoti. Apibendrinus autorių mintis galima išskirti, kad motyvacija apima sąmoningą norą kažką gauti ir ji neapsiriboja vien pinigais ar noru išvengti bausmès.

Kita vertus, asmenys ne visada supranta, kokie motyvai juos skatina, bet žino, kokių tikslų siekia. Be to, motyvacija turi dvi svarbias sudedamąsias - impulsą ir patị motyvą. Impulsas yra vidinis procesas, kuris skatina veikti, o motyvas generuoja elgesị ir padeda žmogui siekti tikslo, kuris kaip atlygis paprastai tenkina asmens vidinius poreikius (Rodrigues-Goulart, 2006). Tuo tarpu D. Lipinskienė (2012) išskiria tris pagrindinius motyvaciją skatinančius veiksnius: veiklos (tikslų) nustatymas, veiklos palengvinimas (aprūpinimas būtinais ištekliais, barjerų eliminavimas), skatinimas (atlygio savalaikiškumas, teisingumas, lygybe ir poreikių patenkinimas). Šie universalūs veiksniai, jei yra ịgyvendinami, gali patenkinti žmonių lūkesčius. Deja, motyvacija nèra pastovi būsena, ji kinta, todèl ją reikia periodiškai vis papildyti. Tiek motyvacijos teorija, tiek praktika remiasi nuostata, kad motyvacija gali silpti, t. y. „išsisklaidyti“ (Žaptorius, 2007). Be to, objektyviai gerëjant gyvenimo sąlygoms, žmonès tampa jautresni ịprastiems sunkumams. Tad rezultatas yra - ne pasitenkinimas, o įtampa ir nuovargis arba nuobodulys, persisotinimas ir neviltis (Kuzmickas, 2018). Tai įvertinus galima teigti, kad motyvacija iš esmès yra subjektyvus dalykas, todèl institucijai tenka nelengva užduotis organizuoti, palaikyti ir nuolat gerinti motyvacinę sistemą, iš jos reikalaujama, kad institucijos veikla būtų ne tik veiksminga ir sẻkminga, bet ir būtų patenkinti žmonių lūkesčiai. Juolab kad motyvacija gali būti priskirta latentiniams reiškiniams, kai tiriant nèra garantijų, kad matuojami dydžiai galès būti išreiškiami ir tai nulems žmonių pažiūras bei elgesị (Marcinkevičiūtè, 2010). Vis dèlto akivaizdu, kad veiksminga motyvavimo sistema yra puiki priemoné, kariuomenei siekiant išnaudoti visus savo pajègumus ir palaikyti kovinę parengtį.

Paprastai kariuomenė grindžiama biurokratiniu valdymu, todèl mokslininkai ịžvelgia tokios struktūros reformavimo ir tobulinimo poreikį. Šiuo metu Krašto apsaugos sistemoje kariams taikomos suformuotos motyvacinès priemonès yra abstrakčios ir nekonkrečios. Todèl motyvavimo procese galima tikètis ir tokių pat neaiškių rezultatų. Taigi sudarant perspektyvinius karių motyvavimo planus svarbu, kad visi kariai (individualiai) būtų motyvuoti siekti kariuomenès veiklos tikslų. Suvokusi, kad kariai sieks tikslų tik patenkinę savo lūkesčius, kariuomenès vadovybė turi priimti iššūkị taip tobulinti savo motyvacinę sistemą, kad galètų ne tik pritraukti, bet ir kuo ilgiau išlaikyti tarnyboje šiuolaikinị karị. R. Steiger'io ir U. Zvygard'o (1999) teigimu, reikia daryti viską, kad karo tarnyba būtu patrauklesnè ir veiksmingesnè, tik būtina atminti, kad tai visgi yra tarnyba. Be to, verta paminèti, kad motyvacijos koncepcija susijusi su tam tikro laikotarpio vertybèmis, kurios pripažistamos tarnyboje. 


\section{Vertybių reikšmė karių motyvacijos procese}

Vertybės, kaip tam tikros civilizacijos išraiška, egzistuoja visose žmonijos kultūros epochose ir kiekvieno žmogaus sąmonèje. İskiepytos vertybės, vertybinès orientacijos atskleidžia ne tik žmogaus nuostatas, bet ir visos visuomenės vertybių sistemą (Genzelis ir kt. 2008). B. Kuzmicko (2001, p. 60) teigimu, „vertybės išreiškia ne tai, kas faktiškai yra, buvo ar galètų būti, bet tai, kas turètų, privalètų būti, net jei tas privalèjimas negali būti visiškai ịgyvendintas“. Lietuvos Respublikos nacionalinio saugumo strategijoje (2017) vertybių krizè įvardijama kaip vienas iš nacionalinio saugumo pavojų. Todèl dabar „,mums reikalingas pasitikejjimas savimi bei tradicinès vertybès - pagarba ịstatymui ir tvarkai, drausmé, santūrumas, gebẻjimas susitarti, nerèksmingas patriotizmas, tolerancija“ (Laurinkus, 2010, p. 104). Vertybės, kaip žmonijos idealas, nepaprastai reikšmingos ir prasmingos tiek asmeniniame, tiek visuomenès gyvenime. Todèl jos yra mokslininkų ir piliečių dèmesio centre.

Kariuomenèje vertybės ypač svarbios. M. Adivar'as ir Sh. Rivnai-Bahir'as nustatè, kad esminiai pastaraisiais dešimtmečiais Izraelio visuomenès vertybių sistemoje ịvykę pokyčiai paveikè jaunimo požiūrị ị kariuomenę ir jų motyvaciją, sprendžiant tarnauti savanoriais ar atliekant privalomają karo tarnybą (remiantis Vileikienė ir kt., 2015). Kariuomenès vertybès yra visa ko pagrindas ir pagrindiniai principai, kurie išlieka pastovūs kiekvienoje situacijoje, nes turi ịtakos tam, ką karys daro ar ko nedaro. Vertybès neatsiejamos nuo motyvacijos sampratos - tai žmonių elgesị reguliuojanti jèga. Vertybès - tai tarsi ,išankstinë“ motyvacija (aš noriu elgtis, atsižvelgdamas ị savo vertybes) ir, atlikus veiksmus, leidžia ịsivertinti (ar aš veikiau, atsižvelgdamas ị savo vertybes?) elgesị (The army leadership code). Lietuvos kariuomenès vado J. V. Žuko teigimu, ,vertybės padeda nepalūžti ir apsispręsti, kuriuo keliu toliau eiti, net ir esant sunkiausioms gyvenimo situacijoms. Tai patikrinta. Jei Lietuvoje nebūtų radęsi piliečių, kurie vadovaudamiesi šiomis vertybėmis, iškilus pavojams, ėmè ị rankas ginklus, tapo kovotojais ir gynė Lietuvos Laisvę, šiandien, ko gero, negalètume savęs vadinti lietuviais, kalbėti lietuviškai, didžiuotis savo garbinga istorija (Išbandyk save, 2016).

Lietuvos kariuomenès vertybès yra oficialiai patvirtintos Lietuvos karinèje doktrinoje: patriotizmas, ištikimybė, pasiaukojimas, sąžiningumas, drąsa, pagarba, garbè, principingumas. Pastebètina, kad Lietuvos kariuomenès vertybės panašios i kitu šalių: JAV, Kanados, Didžiosios Britanijos ir kt. Be abejo, šalių kariuomenių vertybės kažkiek skiriasi, nes atskleidžia konkrečios šalies visuomenės vertybines nuostatas, kurias lemia ekonominè, politinè ir socialinè aplinka (Neimontas, 2013). Šiuolaikinio kario etosas turi apimti tiek karinę dvasią, t. y. tokias savybes kaip pasiaukojimas, drausmė, didvyriškumas, šaunumas, tiek civilinès visuomenės 
deklaruojamas vertybes, tokias kaip supratingumas, atsakomybè, tolerancija, atsidavimas (Genzelis ir kt. 2008). Akcentuotina, kad karinès vertybès telkia ir stiprina karius kaip asmenybes. Vis dèlto šiandien, A. Pocienès (2018, p. 391) teigimu, „vertinant pritraukimo galimybes, pirmiausia svarbu suprasti vertybini kontekstą, kuriame socializuojasi jaunuoliai, taip pat reikia identifikuoti specifinius, būtent jaunosios kartos, prioritetus, vadovaudamiesi kuriais jie priima sprendimus“. Taigi ypač svarbu suderinti karinès institucijos ir karių vertybių sistemą (Zaman Ahman, 2010).

Nors karių tarnybos motyvavimo būdų paieška yra aktuali ir tyrinètojų akcentuojama problema, visgi motyvaciją lemia ne tik formalios procedūros - būtinos vertybès ir jas reikia puoselèti. Šiuolaikinis karys kovoja ne su konkrečiu blogiu, o dèl abstraktaus gèrio (angl.force for good) (Deksnys, 2011). Taigi apibendrinant galima teigti, kad motyvavimo procesas susijęs su tam tikrų vertybių įtvirtinimu, todèl karių tarnyboje jos - neatsiejama gyvenimo dalis.

\section{Tyrimo duomenys ir jų analizė}

Kariuomenè yra civiliams uždara institucija, todèl pirmiausia tyrimui atlikti gautas Sausumos pajègų, pasirinkto bataliono vado leidimas atlikti tyrimą. $2018 \mathrm{~m}$. kovo mėnesį atliktas kiekybinis tyrimas, anoniminė anketinė apklausa. Remiantis mokslo informacijos šaltiniais, parengtas klausimynas nuolatinès privalomosios pradinès karo tarnybos kariams. Straipsnio autorès sudarytą tyrimo instrumentą sudaro 30 uždarojo ir atvirojo pobūdžio klausimų.

Pasirinkti respondentai buvo nuolatinès privalomosios pradinès karo tarnybos kariai, atliekantys pradinę karo tarnybą viename iš Lietuvos kariuomenès Sausumos pajègų batalionų. I̦ ši kiekybinio tyrimo ribojimą būtina atsižvelgti apibendrinant tyrimo rezultatus.

Tyrimo imčiai sudaryti taikyta tikimybinè paprastoji atsitiktinè vienmomentė tirtų karių atranka. Imties dydis prieš apklausą $n=579$ kariai, po apklausos $n=$ 561 karys $(96,89$ proc.). Suvedant duomenis į SPSS17 statistinę programa, pastebèta, kad dalis anketų užpildytos tik iš dalies arba nekorektiškai, todèl ị tyrimo duomenų analizę jos neịtrauktos. Atliekant tiriamujų duomenų analizę naudotos 507 respondentų užpildytos anketos. Nagrinèjant pasirinktą tyrimo imtį nustatyta, kad skyrèsi karių atejjimo ị tarnybą pobūdis: daugiau nei pusè $(60,9$ proc. $n=309)$ karių teigè, kad tarnauti atėjo savanoriškai, likusi dalis $(39,1$ proc. $n=198)$ - laikydamiesi privalomos tvarkos. Tyrime dalyvavo tiek moterys $(4,54$ proc. $n=23)$, tiek vyrai $(95,46$ proc. $n=484)$, tiriamujų dažniausia žymètas amžius - nuo 21 iki $26 \mathrm{~m}$. (54 proc. $n=274)$, mažiau žymètas - iki $21 \mathrm{~m}$. $(43,2$ proc. $n=219)$ ir labai maža dalis - nuo 27 metų ir daugiau $(2,8$ proc. $n=14)$. Analizuojant duomenis apie 
respondentų išsilavinimą, atsakymo variantai pasiskirstė taip: daugiau nei pusė turèjo vidurinị (54 proc. $n=279)$, trečdalis - vidurinị specialujji profesinį $(33,5$ proc. $n=170)$, mažiau nei dešimtadalis - aukštajị neuniversitetini $(6,7$ proc. $n=34)$ arba aukštajị universitetinị $(5,3$ proc. $n=27)$ išsilavinimą.

Tiriamieji norą dalyvauti tyrime patvirtino žodiniu sutikimu. Tyrimas atliktas lokalizuotoje vietoje, tačiau imtis reprezentatyvi, todèl gauti rezultatai leido atskleisti NPPKT karių tarnybos motyvacijos probleminę situaciją. Toliau pateikiami tyrimo rezultatai.

\subsection{Tyrimo rezultatai}

Visų pirma aptariami NPPKT karių tarnavimo kariuomenèje motyvai. Nustatyta, kad dažniausia NPPKT kariai pasirinko tarnybą dẻl to, kad norèjo ịgyti karinių žinių ir praktinių igūdžių (36,5 proc.) arba buvo pašaukti atlikti NPPKT (32,7 proc.); daugiau nei dešimtadalis pasirinko dèl galimybès realizuoti savo gebejjimus ir patirtị (13,4 proc.); nedidelè dalis pasirinko, nes turi norą ginti Tèvynę (6,7 proc.) ar dèl patriotizmo (6,1 proc.); mažiausiai karių pasirinko tarnybą dèl tinkamo užmokesčio (3,2 proc.), nedarbo (2 proc.) ar todèl, kad čia nereikia prisiimti didelès atsakomybės (1,4 proc.). Svarbu buvo išsiaiškinti ir tai, ar savanoriškai ir privaloma tvarka tarnaujantys kariai yra patenkinti tuo, kad atejo į Lietuvos kariuomenès tarnybą. Tyrimo rezultatai leidžia teigti, kad daugelis savanoriškai tarnaujančių karių yra patenkinti (43,04 proc.); šiek tiek mažiau jų teigè, kad nei taip, nei ne (41,42 proc.); maža dalis - nepatenkinti (15,53 proc.). Visai kitaip mano privaloma tvarka tarnaujantys kariai: didžioji jų dalis žymėjo savo atsakymuose nei taip, nei ne (47,47 proc.), daugiau nei trečdalis - nepatenkinti $(39,39$ proc.) ir tik maža dalis liko patenkinti (13,13 proc.), kad atèjo ị Lietuvos kariuomenès tarnybą. Skirtumas tarp šių grupių yra statistiškai reikšmingas. Paklausus, ar būtų tarnavę kariuomenèje, jei nebūtų šauktinių prievolès, paaiškèjo, kad daugiau nei pusė netarnautų (57,4 proc.); šiek tiek mažesnè dalis - tarnautų (42,6 proc.).

Karių paprašyta prisiminti savo pirmaji ịspūdị apie tarnybą ir nurodyti, kaip ją vertina dabar. Atsakymai pateikti 1 paveiksle.

Daugiausia privaloma tvarka tarnaujančių (41,41 proc.) ir savanoriškai tarnybą pasirinkusių (37,54 proc.) karių teigè, kad lyginant su pirmuoju įspūdžiu tarnybą dabar vertina blogiau, nei tikejjosi; taip blogai, kaip ir tikejjosi, vertina beveik trečdalis privaloma tvarka tarnaujančiųų (29,29 proc.) ir dešimtadalis savanoriškai tarnybą pasirinkusiujų (10,68 proc.); taip gerai, kaip ir tikejjosi, - trečdalis savanoriškai pasirinkusiujų tarnybą (33,66 proc.) ir šeštadalis - privaloma tvarka tarnaujančiujų (16,67 proc.); geriau, nei tikèjosi, - beveik penktadalis savanoriškai tarnybą pasirinkusiųu ų (18,12 proc.) ir šiek tiek daugiau nei dešimtadalis - priva- 


\section{Gerda Baltutytė}

loma tvarka tarnaujančiujų (12,63 proc.). Skirtumas tarp šių grupių yra statistiškai reikšmingas.

Ne mažiau įdomus buvo ir pačių karių savo tarnybos vertinimas. Daugiausia savanoriškai tarnybą pasirinkusių karių savo tarnybą įvertino gerai: dienos tarnybos vykdymą ( 51,1 proc.); kovinio šaudymo pratybas ( 36,9 proc.); kolektyvini karinị rengimą kuopoje (49,5 proc.); individualų karinị rengimą (44,7 proc.); fizinį pasirengimą (45,6 proc.). Panašūs ir privaloma tvarka tarnaujančių karių rezultatai - ir jie tarnybą ịvertino gerai: dienos tarnybos vykdymą (50,0 proc.); kovinio šaudymo pratybas (33,8 proc.); individualų karini rengimą kuopoje ( 42,4 proc.); fizinị pasirengimą (47,0 proc.); tik kolektyvinị pasirengimą kuopoje (37,4 proc.) daugiausia prievolininkų įvertino patenkinamai. Nustatyta, kad NPPKT kariai išskiria gebejjimus, kurie kariui tarnyboje yra būtini: greitai vykdyti paskirtą užduotị (79,7 proc.); šiek tiek mažiau - laiku užbaigti pradètą užduotị (66,1 proc.) ir vadovauti, kontroliuoti (64,7 proc.); šiek tiek daugiau nei pusè - mokyti kitus (56,6 proc.) ir numatyti užduočių perspektyvas (53,6 proc.); šiek tiek daugiau nei trečdalis - diegti inovacijas ( 36,1 proc.); maža dalis pasirinko atsakymą kita $(8,9$ proc.).

Paklausus, kokios savybės labiausiai trūksta NPPKT kariams, NPPKT kariai dažniausia ịvardijo, kad trūkta aktyvumo ir iniciatyvumo ( 23,1 proc.); patriotizmo (22,3 proc.); pagarbos (19,1 proc.); šiek tiek mažiau nurodè, kad nieko netrūksta (12,2 proc.) arba trūksta pasitikèjimo savimi (9,3 proc.), sąžiningumo (7,1 proc.); mažiausiai - drąsos ( 3,6 proc.) ir principingumo $(3,4$ proc.).

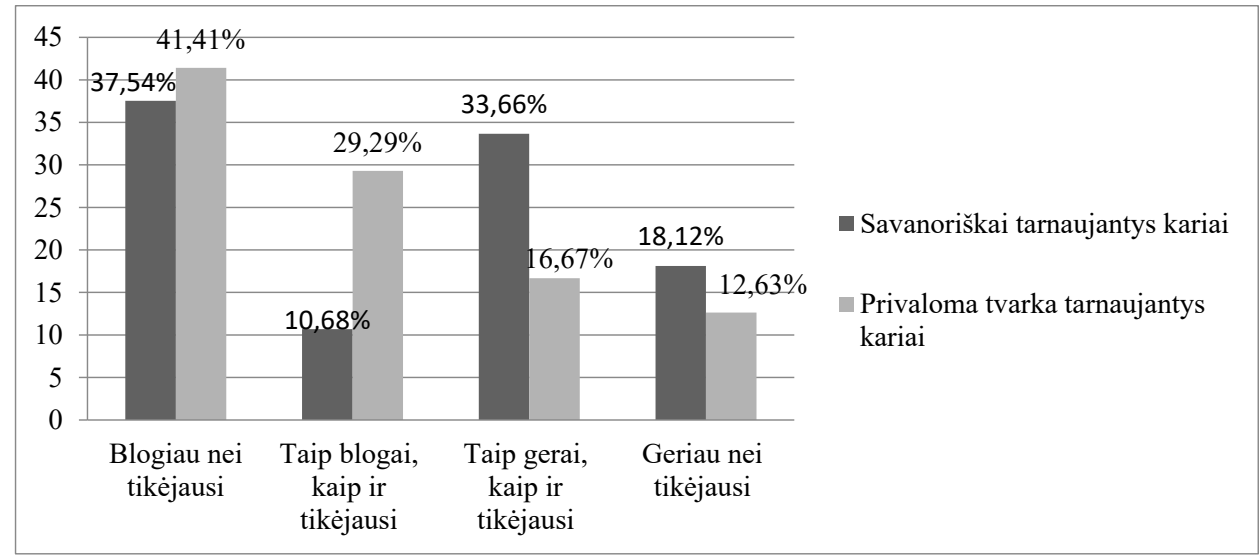

1 pav. Savanoriškai ir privaloma tvarka tarnaujančių karių pirmasis įspūdis apie tarnybą

Fig. 1. The first impression of volunteer soldiers and conscript soldiers about military service 
Analizuojant vieną svarbiausių karių tarnybos motyvacijos klausimų, respondentų klausta, ar būtina karị motyvuoti. Absoliuti dauguma karių (84 proc.) teigè, kad tai būtina, nes tik motyvuotas karys siekia ir pasiekia gerų rezultatų; dešimtadalis (10,1 proc.) teige, kad pakanka vidutinès motyvacijos; maža dalis (5,9 proc.) tam reikšmès neteikè. Tikslinga pažymèti, kad esama Lietuvos kariuomenès karių tarnybos sistema pusè karių buvo iš dalies patenkinti (50,3 proc.); šiek tiek mažiau nei pusè - nepatenkinti (44,6 proc.) ir tik labai maža dalis - patenkinti (5,1 proc.). Kadangi tik labai maža dalis karių liko patenkinti Lietuvos kariuomenès tarnybos motyvacine sistema, jų paprašyta ịvardyti priežastis, kodèl jie iš dalies arba visiškai nepatenkinti šiuo metu esama motyvacine sistema: trečdalis respondentų paminejjo netobulą skatinimo sistemą ( 33,9 proc.); šiek tiek mažiau pažymėjo, kad kartais skatinami ne tie kariai, kurie nusipelnè (26,4 proc.); daugiau nei dešimtadalis - ne visada aišku, už ką skatinama (15,8 proc.), arba gaunami tik padèkos raštai, kurie nieko verti (14,2 proc.); mažiausiai - kita (6,3 proc.). Siekta išsiaiškinti, ar patys kariai jaučiasi motyvuoti tarnyboje siekti gerų rezultatų (2 pav.).

Daugiausia savanoriškai tarnybą pasirinkusių ( 49,84 proc.) ir privaloma tvarka tarnaujančių (42,93 proc.) karių atsakè, kad nei jaučia, nei nejaučia esą motyvuojami tarnyboje siekti gerų rezultatų; jaučia esą motyvuojami daugiau savanoriškai tarnybą pasirinkusių (32,04 proc.) nei privaloma tvarka tarnaujančiu (17,17 proc.) karių; nejaučia - daugiau privaloma tvarka tarnaujančių (39,90 proc.) nei savanoriškai tarnybą pasirinkusių karių (18,12 proc.). Skirtumas tarp šiu grupių yra statistiškai reikšmingas. Statistinès analizès rezultatai atskleide ir tai, kas silpnina karių motyvaciją: neracionalus tarnybos organizavimas (27,4 proc.); neịdomi tarnyba (17,4 proc.); per mažas darbo užmokestis (17,2 proc.); šiek tiek mažiau karių pažymėjo, kad tarnyba susijusi su didele nervine įtampa (14 proc.); mažiau nei dešimtadalis - varginanti tarnyba ( 9,1 proc.), nevienodai paskirstytas tarnybos krūvis (9,1 proc.), kita (6,1 proc.).

Kitas aktualus aspektas, kada NPPKT kariai tarnautu geriau. Didžioji dalis respondentų teigè, kad geriau tarnautų, jei tarnyba teiktų malonumą (30,2 proc.) arba tarnybos krūvis atitiktų užmokestị (22,9 proc.); šiek tiek mažiau - tarnauja ir taip gerai (15,8 proc.) arba geriau tarnauti nemato prasmès (13,0 proc.); mažiausiai jei turètų daugiau sugebejjimu ( 6,7 proc.), fizinès ištvermès ( 6,5 proc.), matytų realias karjeros siekimo galimybes (4,9 proc.). Tarnybos motyvacijai ịtaką daro ir nematerialūs skatinimo būdai. Čia būdingas gana ryškus išskyrimas: maloniausias nematerialus tarnybos skatinimo būdas - laisvadienis (70,4 proc.); nedidelè dalis pažymėjo pagyrimą (14,8 proc.); mažiausiai - laisvalaikio programas (6,5 proc.), sudètingos užduoties skyrimą ( 6,3 proc.), kita (2 proc.).

Svarbu išsiaiškinti, kaip patys kariai vertina Krašto apsaugos pajègas (žr. 3 pav.). Daugiausia savanoriškai tarnybą pasirinkusių karių Krašto apsaugos 


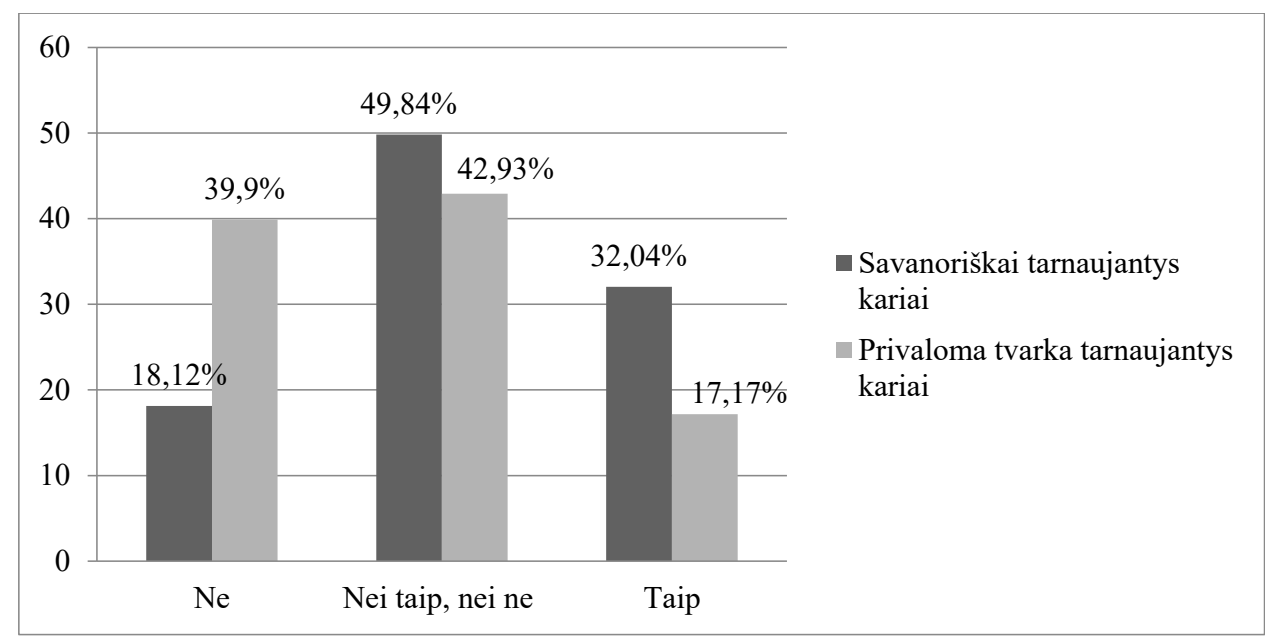

2 pav. Savanoriškai ir privaloma tvarka tarnaujančių karių motyvacija tarnyboje siekti gerų rezultatų

Fig. 2. Motivation of volunteer soldiers and conscript soldiers to seek for good results in military service

pajègas vertina patenkinamai (46,60 proc.) arba gerai (43,69 proc.); maža dalis puikiai $(4,85$ proc.) ir blogai (4,85 proc.). Daugiausia privaloma tvarka tarnaujančių karių Krašto apsaugos pajègas vertina patenkinamai (44,95 proc.) arba gerai (39,39 proc.); dešimtadalis - blogai (11,62 proc.); maža dalis ( 4,04 proc.) - puikiai. Skirtumas tarp šių grupių yra statistiškai reikšmingas. Be to, nustatyta, kad didelè dalis $(67,68$ proc.) privaloma tvarka tarnaujančių karių išvis negalvoja apie tolesnę profesinę karo tarnybą; ketvirtadalis (25,25 proc.) - gal kažkada ateityje; maža dalis $(7,07$ proc.) galvoja apie tolesnę profesinę karo tarnybą. Didesnè dalis $(37,86$ proc.) savanoriškai tarnybą pasirinkusių karių galvoja, kad gal kažkada ateityje eitų ị profesinę karo tarnybą; trečdalis (33,3 proc.) apie tai negalvoja; šiek tiek mažesnè dalis $(28,80$ proc.) apie tolesnę profesinę karo tarnybą galvoja. Skirtumas tarp šių grupių yra statistiškai reikšmingas.

Daug diskusijų visuomeneje ir valstybejje keliantis klausimas dèl visuotinio šauktinių šaukimo vis dar neišspręstas, todèl karių klausta, kaip jie mano, ar būtų tikslingas visuotinis šaukimas. Beveik pusė jų (49,1 proc.) teigè, kad visuotinis šaukimas netikslingas; šiek tiek daugiau nei trečdalis $(35,3$ proc.) mano, kad tikslingas; daugiau nei dešimtadalis (15,6 proc.) tinkamiausio sprendimo nežino.

Nors kariuomenei skiriama vis daugiau demesio ir išteklių, atlikto tyrimo rezultatai atskleidè, kad pasitenkinimas NPPKT tarnyba - ne toks jau didelis, ypač nepatenkinti privaloma tvarka tarnaujantys kariai, palyginti su savanoriškai tarny- 


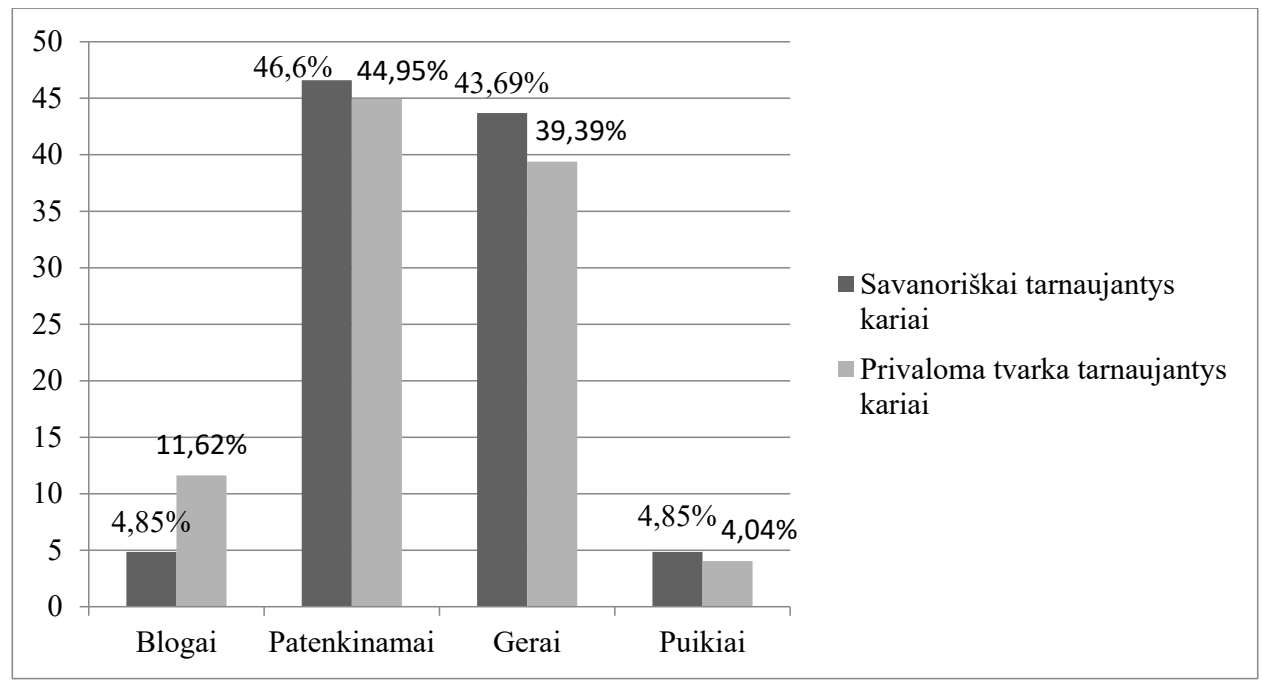

3 pav. Savanoriškai ir privaloma tvarka tarnaujančių karių Lietuvos kariuomenès Krašto apsaugos pajègų vertinimas

Fig. 3. Opinion of volunteer soldiers and conscript soldiers towards the National Defense Forces of the Lithuanian Armed Forces

bą pasirinkusiaisiais. Pasiūlymų, kaip reikètų gerinti karių tarnybos motyvacinę sistemą, pateikè šiek tiek daugiau nei pusė karių (52,1 proc.); mažiau nei pusė (47,9 proc.) pasiūlymų nepateikè. Svarbu, kad kariai nevengè išsakyti savo kritinès nuomonès apie nuolatinę privalomąą pradinę karo tarnybą, tai leidžia įsiklausyti ị jų nuomones. Pateikti pasiūlymai ar pastebejjimai buvo sugrupuoti į kelias pagrindines kategorijas (1 lentelè).

1 lentele. Savanoriškai ir privaloma tvarka tarnaujančių karių pasiūlymai dèl motyvacijos tarnauti gerinimo

Table 1. The volunteer soldiers and conscript soldiers suggestions to improve for military services motivation

\begin{tabular}{|l|l|}
\hline Kategorijos pavadinimas & Patvirtinantys teiginiai \\
\hline Materialus skatinimas & $\begin{array}{l}\text { „Didesnės išmokos“; ,,mokèti kariams kelionpinigius i } \\
\text { namus ir iš jų“; ,papildomas mokestis už pratybas“; , ,būtų } \\
\text { didesni pinigai, būtų daugiau savanorių“ }\end{array}$ \\
\hline Nematerialus skatinimas & $\begin{array}{l}\text { „Reikia išeiginių“; ,,daugiau renginių“; ,noriu viktorinų“; } \\
\text { „dažniau skiriami laisvadieniai“" }\end{array}$ \\
\hline
\end{tabular}


Gerda Baltutytė

\begin{tabular}{|c|c|}
\hline Kategorijos pavadinimas & Patvirtinantys teiginiai \\
\hline Kvalifikuotas personalas & $\begin{array}{l}\text { „Labiau kvalifikuotų skyriaus vadų, kurie išmano savo } \\
\text { darbą““; „reikia išsilavinusių darbuotojų, kurie myli ir gerbia } \\
\text { savo darbą"“; „mažiau jaunų vadų“; , ,kelti aukštesnius stan- } \\
\text { dartus skyrių vadams“ }\end{array}$ \\
\hline Pratybos & $\begin{array}{l}\text { „Daugiau užsièmimų ir praktikos“; , „idomesnių užduočių } \\
\text { per pratybas“; ,,daugiau šaudymo pratybų“; , ,daugiau skir- } \\
\text { tingų pratybų, o ne tų pačių pratybų kartojimas“; ,„daugiau } \\
\text { pratybų mieste“ }\end{array}$ \\
\hline Karinis aprūpinimas & $\begin{array}{l}\text { „Pagerinti aprūpinimą amunicija“; ,,daugiau šovinių praty- } \\
\text { boms“; , ,daugiau įrangos“; ,geresnès ekipuotės“ }\end{array}$ \\
\hline Didesnè motyvacija & $\begin{array}{l}\text { „Neịmanoma įdiegti motyvacijos per prievartą atsiųstiems } \\
\text { kariams“; ,,kalbėti su kariais, kodėl turètų geriau tarnauti“; } \\
\text { „daugiau motyvaciją keliančių paskaitų“; „,motyvacijai } \\
\text { svarbūs paskatinimai“; ,,demotyvuoja rutina“; ,,atrinkti } \\
\text { tarnauti tik motyvuotus karius““ }\end{array}$ \\
\hline Kiti pasiūlymai & $\begin{array}{l}\text { „Geresnio maitinimo“; ,,atliktų tarnybą tik savanoriai“; } \\
\text { „,daugiau laiko individualiam sportui“; ,tikslingesnio } \\
\text { tarnybos planavimo“; ,disciplinos, pagarbos lavinimas“; } \\
\text { „,skirstyti užduotis panašiai kariams““ }\end{array}$ \\
\hline
\end{tabular}

Tyrimo dalyvių atsakymai atskleide, kad būtini kompleksiniai veiksmai, kurie lemia, jų manymu, nuolatinès privalomosios pradinès karo tarnybos motyvaciją. Išskiriamas tiek materialus, tiek nematerialus tarnybos skatinimas. Kariams, be abejo, svarbūs tarpasmeniniai santykiai su vadais, kokie vadai dirba, kas juos moko įvairių karinių ịgūdžių. Atkreiptinas dèmesys ị tai, kad pratybų kokybė ir karinis aprūpinimas kol kas nèra stiprioji kariuomenès pusè ir tai gali būti nusivylimo tarnyba priežastis. Be to, svarbu didinti motyvaciją. Kariai ypač akcentavo, kad labiausiai motyvuoti gali būti tie kariai, kurie savanoriškai pasirinko tarnybą. Pažymètina, kad tarnybos organizavimo metodai turètų būti nukreipti ị tai, kaip išvengti tarnybos monotoniškumo, užtikrinti optimalų užduočių pasiskirstymą. Buvo ir kitų svarbių siūlymų, siekiant patenkinti karių lūkesčius, kurie kaip reikšmingos detalès didina motyvaciją. Dèl šios priežasties dalis siūlymų turètų būti apsvarstyti ir kritiškai įvertinti.

\subsection{Tyrimo rezultatu aptarimas}

Atsižvelgiant ị NPPKT karių motyvus tarnauti, nustatyta: kaip priimtiniausią tarnavimo variantą respondentai pasirinko teiginị ,,noras ịgyti karinių žinių ir praktinių ịgudžių“. A. Pocienès (2018) pateikti tyrimo rezultatai pristato 2015-2016 m. „pirmosios bangos“, sugrąžinus NPPKT, šauktinių nuomones. Taigi pirmoji 
paskata tapti šauktiniu kariu - siekis išmokti apginti savo šeimą, tėvynę, kilus grèsmei. Kitas pagal svarbą šauktiniams kariams - noras patirti nuotykių ir išbandymų. Palyginus šių dviejų tyrimų rezultatus galima teigti, kad NPPKT karių tarnybos motyvacija pagrịsta instituciniu motyvacijos tipu. Be to, tyrimas atskleide, kad tarnyba labiau yra patenkinti savanoriškai ją pasirinkę kariai nei privaloma tvarka tarnaujantieji. Tačiau, jei nebūtų šauktinių prievolès, daugelis karių teigè, kad apskritai netarnautų kariuomenèje.

Remiantis V. H. Vroom'o lūkesčių teorija, galima teigti, kad tyrime dalyvavusių karių lūkesčiai buvo patenkinti tik iš dalies. Pažymėtina, kad, remiantis mokslo studija „Motyvacija tarnauti Lietuvos kariuomenèje“ (Vileikienè, Pocienè, Aleknevičienè, 2015), didžioji dalis Krašto apsaugos savanorių pajègose tarnaujančių karių teigè, kad palyginus lūkesčius, kurių turèjo prieš tarnybą ir po jos, daugelis jų tarnybą vertina taip gerai, kaip ir tikèjosi.

Atkreiptinas dėmesys, kad kariai išskyrè šiuos tarnyboje būtinus gebėjimus: greitai vykdyti paskirtą užduoti, laiku užbaigti pradètą užduotị, vadovauti ir kontroliuoti. Daugelis savanoriškai tarnybą pasirinkusių ir privaloma tvarka tarnaujančių karių savo pastarujų mėnesių tarnybą vertina gerai. Darbo autorè neturèjo galimybės palyginti šių rezultatų su karių vadų rezultatais, kaip jie vertintų tuos karius. Tačiau interpretuojant šiuos duomenis, dera prisiminti V. H. Vroom'o lūkesčių teoriją, kurioje pabrèžiama, kad, norint pasiekti tam tikrų tikslų, būtini atitinkami gebejjimai. Todèl darome prielaidą, kad kariai geba tinkamai vykdyti tarnybą, tačiau čia iškyla kitas probleminis klausimas, ar jie turimą potencialą išnaudoja? Karių teigimu, jiems patiems pradinèje karo tarnyboje labiausiai trūksta aktyvumo ir iniciatyvumo.

Kaip minèta teorineje dalyje, tarnybos motyvacija yra svarbi, atliktas tyrimas patvirtino, kad karius motyvuoti būtina, nes tik motyvuotas karys siekia ir pasiekia gerų rezultatų. Tačiau esama karių tarnybos motyvacijos sistema kariai patenkinti iš dalies, nes: netobula skatinimo sistema, kartais skatinami ne tie kariai, kurie nusipelnè, ne visada aišku, už ką skatinama. Galima daryti prielaidą, kad, jei kariai nebus tikri, kad už jų tarnyba atlyginama teisingai, jie nesistengs siekti gerų tarnybos rezultatų, bendrų Krašto apsaugos tikslų. Šie rezultatai suponuoja mintị, kad teoriškai aptarta kario motyvavimo sistema praktikoje veikia visai kitaip nei galbūt tikimasi. Juolab kad patys kariai yra tarsi ,pusiaukeleje“, nes daugelis jų minejjo, kad jaučiasi nei motyvuoti, nei nemotyvuoti tarnyboje siekti geru rezultatų. Tai skatina analizuoti tarnybos motyvacijos sistemos trūkumus, nes nustačius nepasitenkinimo priežastis, paprasčiau būtų galima surasti optimalius sprendimus, kurie tenkintų tiek karius, tiek vadovybę.

Nustatyti statistiškai reikšmingi ryšiai tarp to, kas silpnina karių tarnybos motyvaciją, ir to, kas ją didina. Rezultatai atskleidè, kad karius labiau motyvuo- 


\section{Gerda Baltutytė}

ja tarnybos teikiamas malonumas ar tarnybos krūvị atitinkantis užmokestis, ir atvirkščiai - neracionaliai organizuota, neįdomi tarnyba ir per mažas užmokestis motyvaciją silpnina. Maloniausias nematerialus tarnybos skatinimo būdas - laisvadienis. Tokius pačius rezultatus pateikè ir KAM karo psichologijos skyriaus psichologè kpt. Dainora Kasiliauskyte (2017), atlikusi tyrimą ir apklaususi Kęstučio mechanizuotojo pėstininkų bataliono šauktinius karius. Ji nustatè, kad labiausiai karius motyvuoja ir palaiko galimybe savaitgaliais grị̌ti namo, tuo tarpu draudimas grịžti - viena didžiausių bausmių.

Kariai Lietuvos kariuomenès Krašto apsaugos pajègas vertina patenkinamai, daugelio nuomone, visuotinis šaukimas nebūtų tikslingas. Be to, baigę tarnybą i profesinę karo tarnybą pereiti dažniau mąsto savanoriškai tarnybą pasirinkę nei privaloma tvarka tarnaujantys kariai. Ieškant sprendimo, kas karius labiau motyvuotų tarnauti, pažymėtina, kad daugiau dèmesio reikètų skirti materialiam ir nematerialiam skatinimui, užtikrinti personalo kvalifikaciją, pratybų kokybę, aprūpinimą ir susitelkti ties pačia motyvacija. Šiuo atveju kariai, išsakydami savo nuomonę, prisideda ne tik prie kariuomenès tarnybos vertinimo, bet ir neleidžia ignoruoti akivaizdžių tiesų.

Atliktas kiekybinis tyrimas leido patvirtinti hipotezę, kad savanoriškai ir privaloma tvarka atliekančių NPPKT karių tarnybos motyvacija skiriasi, nes jų karo tarnybą lemiantys lūkesčiai nèra tapatūs. Karo tarnybos motyvacijai esminès įtakos turi savanoriškumo principu grindžiamas atejimas ị karinę tarnybą. Žinoma, straipsnio autores pateiktos interpretacijos gali būti interpretuojamos ir kitaip, tačiau siekta „ne uždaryti“" problemą, o atverti kitų interpretacijų perspektyvą. Todèl nagrinejjant karių tarnybos motyvacijos klausimą vis dar yra erdvès ekspertams ir mokslininkams teikti pasiūlymų ir rekomendacijų, kad karių tarnybos motyvacijos rezultatai būtų geresni.

\section{Išvados}

Motyvuota karinė tarnyba kuriant ir užtikrinant šalies karines galimybes sietina su tarnaujančiais kariais, kurie ịgyvendina karinio saugumo strategijas bei lemia vykdomos veiklos kokybinius rezultatus ir efektyvumą. Atliktas tyrimas atskleidè, kad NPPKT karių lūkesčiai dèl tarnybos pasiteisino tik iš dalies. Suvokus, kad kariai sieks tikslų tik patenkinę savo lūkesčius, svarbu ieškoti būdų, kurie motyvuotų juos tarnauti. Čia ypač svarbus vertybinių nuostatų vaidmuo - karinès vertybès sustiprina ir sutelkia karius kaip asmenybes. Vertindami empirinio tyrimo rezultatus, NPPKT kariai pažymejjo, kad labiausiai jiems patiems trūksta aktyvumo ir iniciatyvumo. 
Šiuo metu Krašto apsaugos sistemoje kariams taikomi motyvacijos veiksniai yra labai abstraktūs, o atliktų mokslinių tyrimų ar studijų dar trūksta, kad būtų galima pagrịsti dabartinès motyvacijos sistemos [ne]sèkmingus ịgyvendinimo rezultatus. Remiantis lokalaus empirinio tyrimo rezultatais nustatyta, kad šiuo metu esama karių tarnybos motyvacijos sistema respondentai patenkinti tik iš dalies. Ivvertinus kiekybinio tyrimo rezultatus, apsiribojant išskirtais instituciniu ir pragmatiniu motyvais, daroma išvada, kad NPPKT karių tarnybos motyvacija pagrịsta instituciniu motyvacijos tipu.

Tarnybos motyvacijai didžiausią ịtaką daro savanoriškumo principu grindžiamas atejimas ị karinę tarnybą. Savanoriškai tarnaujantys kariai yra labiau patenkinti tarnyba ir apie ją yra susidarę geresni ịspūdị, be to, yra labiau motyvuoti siekti gerų tarnybos rezultatų, palankiau vertina Krašto apsaugos pajegas ir mąsto apie tolesnę profesinę tarnybą, nei privaloma tvarka tarnaujantys kariai.

\section{Literatūra}

Baltutytė G. (2019). Lietuvos kariuomenès kariu tarnybos motyvacijos analizé nacionalinio saugumo kontekste. Nacionalinio saugumo studijų programos magistro baigiamasis darbas. Klaipėda: Klaipėdos universitetas.

Battistelli, F. (1997). Peacekeeping and the Postmodern Soldier. Armed Forces \& Society, Vol. 2, p. 467.

Bury, P. (2017). Recruitment and Retention in British Army Reserve Logistics Units. Armed Forces \& Society, Vol. 43 (4), p. 608-631.

Deksnys, G. (2011). Pasitikëjimo kultūros link Lietuvos kariuomenès ịvaizdžio formavimo galimybès. Kaunas: Poezija.

Genzelis, B., Žigaras, F., Kazlauskaitè-Markelienė, R., Petrauskaitè, A. (2008). Šiuolaikinès visuomenès vertybinès orientacijos ir Lietuvos kariuomene. Vilnius: Generolo Jono Žemaičio Lietuvos karo akademija.

Griffith, J. (2008). Institutional motives for serving in the US Army National Guard: Implications for recruitment, retention, and readiness. Armed Forces \& Society, Vol. 34, p. 230-258.

Išbandyk save. (2016). Specialus Lietuvos kariuomenès žurnalo KARYS priedas būsimiems kariams. Prieiga internete:_file:///C:/Users/Vartotojas/Downloads/isbandyk\%20save_.pdf

Jakilaitis, E. (2017). R. Karoblis: nežinia, kiek ilgai kario tarnyba įkvèps vien patriotizmas. Prieiga internete: http:/www.bernardinai.lt/straipsnis/2017-11-24-r-karoblis-nezinia-kiek-ilgai-kario-tarnyba-ikveps-vienpatriotizmas/166441.

Jokubauskas, V. (2014). „Mažujų kariuomenių“ galia ir paramilitarizmas. Tarpukario Lietuvos atvejis. Klaipėda: Klaipèdos universiteto leidykla.

Jonušas, K. (2018). İsitikinti, ar principai geri. Karys, Nr. 4, p. 23-27.

Kasiliauskytè, D. (2017). Ar kario motyvacija - vado elgesio pasekmé? Prieiga internete: https://kariuomene. $\mathrm{kam} . \mathrm{lt} / \mathrm{lt} / \mathrm{tapk}$ _kariu/12/naujienos_3292/ar_kario_motyvacija_vado_elgesio_pasekme.html?pbck=0

Kodèl verta rinktis tarnyba Lietuvos kariuomeneje. (2018). Prieiga internete: http://www.karys.lt/kodel-vertatapti-savanoriu.html.

Kuzmickas, B. (2018). Tarp kaimynu ir pasaulyje vyksmai ir refleksijos. Vilnius: Versmė.

Kuzmickas, B. (2001). Laimé, asmenybè, vertybès. Vilnius: Lietuvos teisès universitetas.

Laurinkus, M. (2010). Kas yra ir gali būti Lietuvos konservatoriai. Lietuviškas konservatizmas. Vilnius.

Levy, Y. (2007). Soldiers as laborers: A theoretical model. Houten: Springer Science + Business Media B.V.

Lietuvos kariuomené pasirengusi iššükiams. (2009). Prieiga internete: file://C:/Users/Vartotojas/Downloads/ lietuvos\%20kariuomene_elektronine\%20versija\%20(3).pdf

Lietuvos Respublikos Seimas. 2017 m. sausio 17 d. Nr. XIII-202. Nacionalinio saugumo strategija. Prieiga internete: https:/e-seimas.lrs.lt/portal/legalActPrint/lt?jfwid=-g0zrzc7sx\&actualEditionId=PnlbjdLoYO\&d ocumentId=TAIS. $167925 \&$ category $=$ TAD. 


\section{Gerda Baltutytė}

Lipinskienè, D. (2012). Motyvuojanti atlygio sistema. Kaunas: Technologija.

Marcinkevičiūtè, L. (2010). Darbuotoju motyvavimo modeliai: teoriniai ir praktiniai aspektai. Kaunas: Akademija.

Maslow, A. H. (2009). Motyvacija ir asmenybė. Vilnius: Apostrofa.

Moskos, C. C. (1977). From Institutional to Occupation. Trends in military organization. Armed Forces \& Society, Nr. 4, p. 41.

Neimontas, M. (2013). Daugiau dèmesio bus skiriama kariuomenès vertybiu puoselejimui. Prieiga internete: http://kariuomene.kam.lt/lt/kariuomenes_atributika/archyvas_2643/2013_m._archyvas/2013_03_naujienu_ archyvas/sausumos pajegose imamasi sistemingai ugdyti kariuomenes_vertybes.html?pbck $=50$

Perry, J. L. (1999) Bringing Society in: Toward a Theory of Public Service Motivation. Fifth National Public Management Research Conference, December 3, 1999. Prieiga internete: http://bush.tamu.edu/pubman/ papers/1999/Perry99.pdf

Pocienè, A. (2018). Lietuvos jaunuolių pritraukimo ị nuolatinę privalomają pradinę karo tarnybą galimybès. Lietuvos metine strategine apžvalga 2017-2018, T. 16, p. 367-392.

Razma, G. (2014). Profesinès karo tarnybos karininku žiniu vertinimas. Žmonių išteklių vadybos studiju programos magistro baigiamasis darbas. Vilnius: Generolo Jono Žemaičio Lietuvos karo akademija.

Rodrigues-Goulart, C. F. (2006). Combat motivation. Military review. November-December. Prieiga internete: https://www.armyupress.army.mil/Portals/7/military-review/Archives/English/ MilitaryReview_20061231_ art016.pdf

Sakalas, A., Šilingienė, V. (2000). Personalo valdymas. Kaunas: Technologija.

Statkus, N. (2003). Etniškumas ir nacionalizmas. Vilnius: Vilniaus universiteto leidykla.

Steiger, R., Zwygart, U. (1999). Karine pedagogika. Vilnius: Generolo Jono Žemaičio Lietuvos karo akademijos leidykla.

Stumbraitė-Vilkišienè, E. (2013). Piliečiu dalyvavimo ir pasitenkinimo squveikos konceptualizacija kuriant viešaja paslauga. Daktaro disertacija. Vilnius: Mykolo Romerio universitetas.

The army leadership code. Prieiga internete: https://www.army.mod.uk/media/2698/ac72021_the_army_ leadership_code_an_introductory_guide.pdf.

Vasiljevas E. (2015). Tarnybos Lietuvos krašto apsaugos savanoriu pajègose motyvu analizè. Taikomosios sociologijos studijų programos magistro baigiamasis darbas. Kaunas: Vytauto Didžiojo universitetas.

Vileikienė, E., Pocienė, A., Aleknevičienė, J. (2015). Motyvacija tarnauti Lietuvos kariuomeneje. Vilnius: Generolo Jono Žemaičio Lietuvos karo akademijos leidykla.

Vroom, V. H. (1994). Work and Motivation. San Francisco: Jossey-Bass Publishers (Originally published: New York: Wiley, 1964).

Zahman Ahman, K. (2010). Aligning military and soldiers' values hierarchy. International Journal of business management, Vol. 5, No. 3, p. 62-69. Prieiga internete: http://citeseerx.ist.psu.edu/viewdoc/download?doi= 10.1.1.1025.1644\&rep=rep $\&$ type $=$ pdf

Žaptorius, J. (2007). Darbuotojų motyvavimo sistemos kūrimas ir jos teorinė analizė. Filososfija. Sociologija, T. 18 , Nr. 4, p. 105-117.

Woodruff, T. D. (2017). Who Should the Military Recruit? The Effects of Institutional, Occupational, and Self-Enhancement Enlistment Motives on Soldier Identification and Behavior. Armed Forces \& Society, Vol. 43 (4) p. 579-607. 


\section{ANALYSIS OF MOTIVATION OF CONTINUOUS \\ MANDATORY INITIAL MILITARY SERVICE: \\ SUBJECTIVE ASSESSMENT OF THE PARTICIPANTS}

\section{Gerda Baltutytè}

Summary

Motivated military service in joint development and ensuring of military security capabilities of the country is related to serving soldiers, who implement the military security strategies and determine the qualitative results and efficiency of the performed activities. The current factors of motivation, applied to the soldiers by the National Defence System of the Republic of Lithuania, are abstract and non-specific. Furthermore, there is too little research or studies to justify the (non) successful results of the current motivation system. Recognizing the importance of military service motivation, there is a need to look for theoretical and empirical assurances which, as a starting point, would allow to assess the motivation of military service.

In Lithuania, the continuous mandatory initial military service (hereinafter referred to as CMIMS) is based not only on the principle of volunteering, but also on coercion (the laws provide for punishment for avoiding mandatory initial military service), therefore, we have not only volunteer soldiers, but also conscript soldiers. It should be noted that, in comparison with 2015, the number of conscript soldiers under mandatory military service increases. The work of the authorities is not just imposition of sanctions, but also to encourage the soldiers to engage in joint activities. In order to get them involved, it is necessary to find out the expectations, the reasons why soldiers decide to participate or remain passive in the service. The scientific and practical problem is formulated by the question of what does determine the motivation of the soldiers, who are under continuous mandatory military service and how do they evaluate the present motivation system of the Lithuanian Armed Forces?

Based on the results of the local empirical research, it was found that the respondents are partly satisfied with the current motivation system of the military service. Upon assessing the results of the quantitative research and limiting it to the identified institutional and pragmatic motives, it is concluded that the motivation of the CMIMS military service is based on the institutional type of motivation.

The motivation of the service is particularly influenced by the voluntary coming to military service. Upon comparing the volunteer soldiers and conscript soldiers, 
are under continuous mandatory initial military service at the same place of service, their service motivation was characterized by statistically significant different: the volunteers are more satisfied with the service and have a better impression of it, are more motivated to achieve good results in the service, have more favourable opinion towards the National Defense Forces and think about further professional service than conscript soldiers.

In addition, based on the theoretical analysis and the results of other authors' research, the active involvement and satisfaction with military service is related to the ability of a soldier to actualize the processes taking place in the world, as well as to personal values and attitudes. Military values strengthen and unite the soldiers as personalities. Values are an important tool for enhancing motivation. Considering the results of the empirical study, CMIMS soldiers have highlighted the lack of activity and initiative.

Finally, it was found that the expectations of CMIMS soldiers have only partially been met. Realizing that soldiers will only seek for their goals, if they meet their expectations, it is important to look for different ways to motivate military service. When looking for a solution to improve the motivation of military service, it should be noted that attention should be paid on the material and non-material promotion of the service, on more qualified staff, on the quality of the exercise, on the provision and on the motivation itself.

While examining the issue of motivation for military service, there is still room for experts and scientists to make suggestions and put forward recommendations to improve the results of motivation for military service.

Gerda Baltutyte் - magistrè (socialiniai mokslai - nacionalinis saugumas), Klaipėdos universiteto Socialinių ir humanitarinių mokslų fakultetas.

Moksliniai interesai: karių tarnybos motyvacija, pilietiškumas, gynybos politika.

Adresas: Vytauto g. 5, LT-92138 Klaipèda.

Tel. +37069612160 .

E-mail: baltutyte.g@gmail.com

Gerda Baltutytè - master of Science of Social Sciences (national security) at University of Klaipeda, Faculty of Social Sciences and Humanities.

Scientific interests: soldiers' service motivation, citizenship, defence policy.

Address: Vytauto Str. 5, LT-92138 Klaipèda, Lietuva.

Phone: +37069612160.

E-mail: baltutyte.g@gmail.com 